Abstracta Iranica Abstracta Iranica

Revue bibliographique pour le domaine irano-aryen

Volume 27 | 2006

Comptes rendus des publications de 2004

« A wonderful world: folios from a dispersed manuscript of the Nuzhat-Nāma ». Muqarnas, XXI, 2004, pp. 95-120.

Annabelle Collinet

(2) OpenEdition

Journals

Édition électronique

URL : http://journals.openedition.org/abstractairanica/6107

DOI : 10.4000/abstractairanica.6107

ISSN : 1961-960X

Éditeur :

CNRS (UMR 7528 Mondes iraniens et indiens), Éditions de l'IFRI

Édition imprimée

Date de publication : 15 mai 2006

ISSN : 0240-8910

Référence électronique

Annabelle Collinet, « «A wonderful world: folios from a dispersed manuscript of the Nuzhat-Nāma ». Muqarnas, XXI, 2004, pp. 95-120. », Abstracta Iranica [En ligne], Volume 27 | 2006, document 236, mis en ligne le 02 janvier 2007, consulté le 25 septembre 2020. URL : http://journals.openedition.org/ abstractairanica/6107 ; DOI : https://doi.org/10.4000/abstractairanica.6107

Ce document a été généré automatiquement le 25 septembre 2020.

Tous droits réservés 


\title{
«A wonderful world: folios from a dispersed manuscript of the Nuzhat- Nāma ». Muqarnas, XXI, 2004, pp. 95-120.
}

\author{
Annabelle Collinet
}

Depuis 1989, Anna Contadini découvre et rassemble des folios dispersés dans sept collections publiques et privées d'Europe et des États-Unis. Ils proviennent d'une copie persane du Nuzhat-nāma-i 'Ala'ī, texte de nature encyclopédique écrit au $6^{\mathrm{e}} / 12^{\mathrm{e}} \mathrm{s}$. par un auteur peu connu, Šāhmardān b. Abi'l-Hูayr Rāzì. Les dix-neuf pages aujourd'hui identifiées de ce manuscrit sont ornées de trente-trois peintures représentant des espèces animales et végétales. A. Contadini identifie et analyse le texte et la graphie de cette copie, ainsi que les liens picturaux existant avec les illustrations des manuscrits d'Ibn BaHtî̌šŭ (Manāfi al-ḥayawān). Elle rassemble ici les pages de ce codex démembré, peut-être réalisé à Qazwīn, et dont la datation pourrait se situer entre la fin du $10^{\mathrm{e}} / 16^{\mathrm{e}}$ et le début $\mathrm{du} 11^{\mathrm{e}} / 17^{\mathrm{e}} \mathrm{s}$. Ces pages n'avaient été jusqu'à présent que partiellement mises au jour et certaines étaient considérées comme issues d'un manuscrit de Qazwīnī ('Aja' ib al-maHlūqāt) ou d'une copie du Manāfi al-hayawān. Quatre folios inédits conservés à Washington (Freer Gallery of Art) et à Harvard (University Art Museums) sont en outre reproduits et étudiés pour la première fois. L'A. prépare une étude plus complète de ce manuscrit et sa traduction, qui permet également de relier le célèbre manuscrit de la Pierpont Morgan Library (M. 500), toujours considéré comme une copie du Manāfi alhayawān, au Nuzhat-nāma. 
INDEX

Thèmes : 5.1. Monde iranophone nompropre Qazwini

\section{AUTEURS}

ANNABELLE COLLINET

Paris 